\title{
Immunological Studies of an Organic Anion-binding Protein Isolated from Rat Liver Cell Plasma Membrane
}

\author{
Allan W. Wolkoff, Alexander Sosiak, Hellen C. Greenblatt, Jos Van Renswoude, and Richard J. Stockert \\ Departments of Medicine and Biochemistry and Liver Research Center, Albert Einstein College of Medicine, Bronx, New York 10461, \\ and National Institutes of Health, Bethesda, Maryland 20205
}

\begin{abstract}
The mechanism of organic anion uptake by hepatocytes has kinetics that suggest facilitated diffusion, and carrier-mediated membrane transport has been postulated. In previous studies, we purified a 55,000 -mol wt organic anion-binding protein (OABP) by affinity chromatography on sulfobromophthalein (BSP)-Sepharose of deoxycholate solubilized liver cell plasma membrane preparations. Using specific goat and rabbit antibodies to $\mathrm{OABP}$, we have now investigated the distribution of this protein in liver fractions and other tissues by an enzymelinked immunosorbent assay and by the immunoblot (Western blot) procedure. These studies indicated that OABP is present in significant amounts in all tissues examined except for blood. Although OABP has not as yet been isolated from each of these tissues and characterized, OABP in heart retained the ability to bind organic anions, and was purified by affinity chromatography on BSP-sepharose. In liver, OABP was membrane bound and remained so after extraction with $0.9 \mathrm{M}$ $\mathrm{NaCl}$, which suggests that it is an intrinsic membrane protein. OABP did not have a ubiquitous subcellular distribution within the hepatocyte. Preparation of subfractions of liver cell plasma membrane revealed that OABP is present in the sinusoidal and absent from the canalicular membrane. Immunofluorescence studies performed in short-term cultured hepatocytes suggest that OABP is associated with the surface of these cells and does not have a significant intracellular distribution.
\end{abstract}

\section{Introduction}

Bilirubin, sulfobromophthalein (BSP), ${ }^{1}$ and other organic anions circulate bound to albumin $(1,2)$. Within the liver, the ligandalbumin complex enters the space of Disse where the ligand interacts with the hepatocyte plasma membrane and enters the cell free of albumin $(3,4)$. The mechanism for organic

A preliminary report of this work was presented at the 34th meeting of the American Association for the Study of Liver Diseases, Chicago, IL, and appeared in abstract form in Hepatology. 1983. 3:875.

Dr. Greenblatt's present address is Clinical Sciences, Inc., 30 Troy Road, Whippany, NJ 07981. Address correspondence to Dr. Wolkoff, Liver Research Center.

Received for publication 9 October 1984 and in revised form 12 February 1985.

1. Abbreviations used in this paper: BSP, sulfobromophthalein; ELISA, enzyme-linked immunosorbent assay; LPM, liver cell plasma membrane; OABP, organic anion-binding protein; PAGE, polyacrylamide gel electrophoresis.

J. Clin. Invest.

(C) The American Society for Clinical Investigation, Inc. 0021-9738/85/08/0454/06 \$1.00

Volume 76, August 1985, 454-459 anion uptake by hepatocytes has kinetics suggesting facilitated diffusion $(5,6)$, and a carrier-mediated membrane transport mechanism has been postulated. The nature of the putative organic anion carrier or carriers is not known. In previous studies (7), we purified a 55,000-mol wt organic anion-binding protein (OABP) by affinity chromatography on BSP-Sepharose of deoxycholate solubilized liver cell plasma membrane preparations. We have prepared specific goat and rabbit antibodies to OABP. Using these antibodies, we investigated the tissue distribution of OABP by the immunoblot (Western blot) procedure, and quantitated OABP in tissues and liver fractions by an enzyme-linked immunosorbent assay (ELISA).

\section{Methods}

Preparation of OABP. Male Sprague-Dawley rats (200-250 g) were obtained from Marland Farms (Peekskill, NY) and fed ad lib. with derived subfraction of liver cell plasma membrane (LPM) was prepared by discontinuous sucrose gradient centrifugation as previously described $(7,8)$. The LPM subfraction (1-2 ml) containing 2-3 $\mu$ g protein $/ \mathrm{ml}$ was mixed with sodium deoxycholate $(0.375 \%$ final volume) and allowed to stand on ice for $30 \mathrm{~min}$. After centrifugation for $20 \mathrm{~min}$ at $10,000 \mathrm{~g}$, the supernate was charged onto a 25-ml GSH-BSP agarose affinity column $(7,9)$. The column was washed with $190 \mathrm{ml}$ of 20 $\mathrm{mM}$ phosphate-buffered saline (PBS) at $\mathrm{pH} 7.4$, and eluted with 0.01 $\mathrm{M}$ Tris, $\mathrm{pH} 8.8\left(4^{\circ} \mathrm{C}\right)$. Protein content in the eluate was determined by the Biorad dye binding assay (10). Analysis of the final preparation by SDS-polyacrylamide gel electrophoresis (PAGE) (11) and isoelectric focusing in $6 \mathrm{M}$ urea (12) revealed a single band when stained for protein (7).

Preparation of antibody to $O A B P$. Goat and rabbit antibodies were prepared by injecting animals with $0.5 \mathrm{ml}$ of Pertussis vaccine (Eli, Lilly, \& Co., Indianapolis, IN), followed $2 \mathrm{~h}$ later by multiple subcutaneous injections with $140 \mu \mathrm{g}$ of OABP in $2 \mathrm{ml}$ homogenized OABP with $3 \mathrm{ml}$ of complete Freunds adjuvant (Sigma Chemical Co., St. Louis, MO). Booster injection of $50 \mu \mathrm{g}$ OABP in incomplete Freunds adjuvant were given every 4-6 wk. The presence of antibody was assessed by ELISA (see below), and antiserum used in these studies had detectable titers of $>1: 4000$.

Preparation of rat organ homogenates. Rats were anesthetized with ether, and organs removed and immediately placed in ice-cold $20 \mathrm{mM}$ PBS, pH 7.6, containing $400 \mathrm{U} / \mathrm{ml}$ aprotinin (Sigma Chemical Co.), 5 mM EDTA, and $0.1 \mathrm{mM}$ phenylmethylsulfonyl fluoride (PMSF, Sigma Chemical Co.). Intestinal mucosal cells were obtained by scraping opened intestine with a glass slide. Organs were homogenized on ice in 8 vol of this buffer using a Polytron type P710/35 (Brinkman Instruments Inc., Westbury, NY) at setting 4 for three 10-s periods. These homogenates were used as antibody absorbent before performing the quantitative ELISA.

In several additional studies, liver membranes were washed in 0.9 $\mathrm{M} \mathrm{NaCl}$ to remove loosely associated proteins. Liver was homogenized in $8 \mathrm{vol}$ of ice-cold $1 \mathrm{mM} \mathrm{NaHCO}, 0.5 \mathrm{mM} \mathrm{CaCl}_{2}, \mathrm{pH} 7.6$, by 15 strokes in a loose Dounce homogenizer. After filtration through two layers of cheesecloth, homogenates were centrifuged at $350 \mathrm{~g}$ for 10 min. The resulting supernatant was centrifuged at $105,000 \mathrm{~g}$ for $3 \mathrm{~h}$ and the pellet resuspended to a total volume four times the original with 2-3 strokes of a loose Dounce homogenizer in $0.9 \mathrm{M} \mathrm{NaCl}, 20$ 
$\mathrm{mM} \mathrm{Na}$ phosphate, $\mathrm{pH}$ 7.4. The suspension remained on ice for 10 min before centrifugation at $105,000 \mathrm{~g}$ for $60 \mathrm{~min}$. These steps were repeated a second time and the final pellet was resuspended in $20 \mathrm{mM}$ PBS, pH 7.4 .

Preparation of liver cell plasma membrane subfractions. Sinusoidal and canalicular-derived plasma membrane subfractions were prepared from rat liver by the rate-zonal centrifugation method of Wisher and Evans $(7,8)$.

Enzyme-linked immunosorbent assay of $O A B P$. The procedure for the ELISA was modified from that previously described (13). A 0.1 $\mathrm{ml}$ aliquot of OABP $(1 \mu \mathrm{g} / \mathrm{ml})$ in $85 \mathrm{mM}$ sodium carbonate, $\mathrm{pH} 9.6$, was added to each well of a 96-well $U$ microtiter plate (Flow Laboratories, Inc., McLean, VA), and incubated at $37^{\circ} \mathrm{C}$ for $1 \mathrm{~h}$. To each well was added $0.2 \mathrm{ml}$ of $5 \%$ BSA (35\% solution, Sigma Chemical Co.) in $50 \mathrm{mM}$ PBS, pH 7.2, containing $0.9 \mathrm{mM} \mathrm{MgCl}_{2}$ (buffer A), and incubation was continued at $37^{\circ} \mathrm{C}$ for an additional hour. Each well was washed six times with buffer A containing 0.5\% Tween 20 (Sigma Chemical Co.) and then aspirated to dryness. Goat antiserum diluted 1:800 (vol/vol) in $0.1 \mathrm{ml}$ of buffer $A$ was added to each well $(0.1 \mathrm{ml})$. Some of these dilutions of sera had been preincubated with known amounts of OABP or membranes (prepared as above) overnight at $4^{\circ} \mathrm{C}$. The plate was again incubated at $37^{\circ} \mathrm{C}$ for $1 \mathrm{~h}$, washed six times with buffer A containing $0.5 \%$ Tween 20 , and aspirated to dryness. Rabbit anti-goat IgG conjugated to horseradish peroxidase (Sigma Chemical Co.), diluted 1:400 (vol/vol) in buffer A was added $(0.1 \mathrm{ml})$ to each well, and the plate was incubated at $37^{\circ} \mathrm{C}$ for $1 \mathrm{~h}$ followed by washing six times in buffer A containing $0.5 \%$ Tween 20 .

To quantitate IgG-associated horseradish peroxidase remaining in each well, $0.1 \mathrm{ml}$ of a solution containing $0.04 \%$ o-phenylenediamine (Sigma Chemical Co.) and $0.01 \% \mathrm{H}_{2} \mathrm{O}_{2}$ in $24 \mathrm{mM}$ citrate, $51 \mathrm{mM}$ phosphate, pH 5.0, was added and the plate was incubated at $37^{\circ} \mathrm{C}$. At $1 \mathrm{~h}, 0.1 \mathrm{ml}$ of $1 \mathrm{~N} \mathrm{NaOH}$ was added to each well, and reaction product was determined in an Artek (Artek Corp., Farmingdale, NY) V-beam computerized ELISA plate reader at $405 \mathrm{~nm}$. In all studies, reaction product resulting from a parallel incubation containing nonimmune serum was subtracted from that resulting with immune serum.

Immunoblot detection of OABP. OABP was detected after SDSPAGE by the method of Towbin et al. (14). Protein samples boiled for $90 \mathrm{~s}$ in $4 \% \mathrm{SDS}, 10 \%$ glycerol, $5 \% \beta$-mercaptoethanol, $0.0625 \mathrm{M}$ Tris, pH 6.8, were resolved on $10 \%$ SDS-PAGE. Proteins were transferred to $0.45-\mu \mathrm{m}$ pore size nitrocellulose paper (Schleicher \& Schuell, Inc., Keene, NH) in a Bio-Rad transblot cell (Bio-Rad Laboratories, Richmond, CA) at $300 \mathrm{~mA}$ for $16 \mathrm{~h}$. After transfer, the nitrocellulose sheet was soaked for $1 \mathrm{~h}$ in $300 \mathrm{ml}$ of $0.35 \%$ BSA in $0.15 \mathrm{M} \mathrm{NaCl}$ containing $50 \mathrm{mM}$ Tris, pH 7.6 (buffer B), followed by $1 \mathrm{~h}$ in $10 \mathrm{ml}$ of goat or rabbit anti-rat OABP or nonimmune serum (1:100 dilution in 3.5\% BSA in buffer B). The sheet was next washed for two 30-min periods in $200 \mathrm{ml}$ of $1 \%$ Tween-20 in buffer B. All procedures were performed at room temperature.

To detect protein-bound IgG on the nitrocellulose, we used rabbit IgG against goat IgG (Cappel Laboratories Inc., Cochranville, PA) or protein A (used in studies of rabbit anti-rat OABP) (Sigma Chemical Co.), which had been radioiodinated by a chloramine-T procedure (15). The nitrocellulose sheet was incubated for $1 \mathrm{~h}$ in $10^{6} \mathrm{cpm}$ of ${ }^{125} \mathrm{I}$ protein in $10 \mathrm{ml}$ of $3.5 \% \mathrm{BSA}$ in buffer B. The sheet was then washed for $30 \mathrm{~min}$ in $700 \mathrm{ml}$ of $1 \%$ Tween 20 in buffer B followed by a second 30-min wash in $30 \mathrm{ml}$ of buffer B. The sheet was blotted dry with paper towels and exposed to Kodak XAR-5 X-ray film (Eastman Kodak Co., Rochester, NY) for $2-48 \mathrm{~h}$ at $-70^{\circ} \mathrm{C}$.

Immunofluorescence studies in short-term cultured hepatocytes. Glass coverslips were sterilized in $95 \%$ ethanol, flame dryed, and placed individually in 35-mm sterile Lux contur plastic culture dishes (Lux Scientific Inc., Newbury Park, CA). To each dish was added 1 $\mathrm{ml}$ of type III calf skin collagen (Sigma Chemical Co.) at $1 \mathrm{mg} / \mathrm{ml}$ in $0.5 \mathrm{~N}$ acetic acid. The dishes were left uncovered in a laminar flow hood and allowed to dry overnight under ultraviolet light.

Rat hepatocytes were isolated after perfusion with collagenase (Worthington, type I) and suspended in medium consisting of Way- mouth's 752/1 (Gibco Laboratories, Grand Island, NY), $25 \mathrm{mM}$ Hepes, pH 7.2, 5\% heat inactivated fetal bovine serum (Gibco Laboratories), $1.7 \mathrm{mM}$ additional $\mathrm{CaCl}_{2}, 5 \mu \mathrm{g} / \mathrm{ml}$ bovine insulin (Sigma Chemical Co.), $100 \mathrm{U} / \mathrm{ml}$ penicillin (Gibco Laboratories), and $0.1 \mathrm{mg} / \mathrm{ml}$ streptomycin (Gibco Laboratories). Approximately $1 \times 10^{6}$ cells in $1 \mathrm{ml}$ were put into each dish and cultured in $5 \% \mathrm{CO}_{2}$ atmosphere at $37^{\circ} \mathrm{C}$. Approximately $2 \mathrm{~h}$ into the culture, medium was changed and cells cultured for a total of 16-18 h (16).

After culture, dishes were washed twice with $2 \mathrm{ml}$ of PBS, pH 7.4. Coverslips were carefully removed with a scalpel and placed in clean 30-mm culture dishes. They were then washed twice with $2 \mathrm{ml}$ PBS, $\mathrm{pH} \mathrm{7.4}$, and fixed in acetone at $-70^{\circ} \mathrm{C}$ for $2 \mathrm{~min}$. Coverslips were washed twice with PBS, pH 7.4, at room temperature. $0.2 \mathrm{ml}$ of goat anti-rat OABP or nonimmune goat serum (1:100 dilution in PBS, $\mathrm{pH}$ 7.4 , containing $0.5 \% \mathrm{BSA}$ ) was placed on each coverslip and incubated for $30 \mathrm{~min}$ at room temperature. Coverslips were then washed twice with $2 \mathrm{ml}$ of PBS, $\mathrm{pH} 7.4$. Subsequently, $0.2 \mathrm{ml}$ of rhodamine conjugated rabbit anti-goat IgG (Cappel Laboratories), 1:100 dilution in PBS, $\mathrm{pH} 7.4$, containing $0.5 \%$ bovine serum albumin was placed on each coverslip and incubated for $30 \mathrm{~min}$ at room temperature. Coverslips were washed twice in PBS, $\mathrm{pH} 7.4$, and mounted on glass slides in Galvatol.

\section{Results}

A standard curve for the ELISA of OABP is seen in Fig. 1 and reveals a $\log$ linear region from $\sim 2-30 \mathrm{ng}$ of protein. Duplicate determinations were within $5 \%$ of each other. The reduction in ELISA reaction product after absorption of the goat anti-OABP with organ homogenates indicated the presence of significant amounts of OABP in all tissues tested (Table I). In all cases, the quantity of homogenate protein was such that the resulting optical density was within the log linear region of the simultaneously performed standard curve. Although homogenates were prepared in the presence of protease inhibitors, it is possible that reduced antibody activity resulted from protease digestion rather than specific absorption of antibody by membrane-bound antigen. For this reason, we directly examined whether these organs contained OABP by the Western blot procedure.

Organ homogenates were subjected to SDS-PAGE and electrophoretically transferred to nitrocellulose. As seen in Fig. 2 , incubation with rabbit anti-OABP followed by ${ }^{125} \mathrm{I}$-protein A revealed a single $55,000-\mathrm{mol}$ wt band in all organs. There was no reactivity seen on Western blot analysis of rat red cells

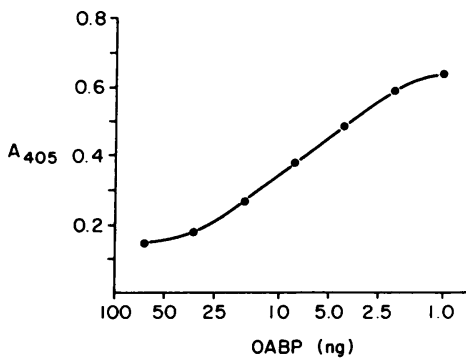

Figure 1. Standard curve for ELISA of OABP. Microtiter plates were coated with OABP $(1 \mu \mathrm{g} / \mathrm{ml})$. Goat anti-OABP (1:800 dilution) was preincubated with known amounts of OABP (abscissa) overnight at $4^{\circ} \mathrm{C}$ before addition to each well. After a $1-h$ incubation at $37^{\circ} \mathrm{C}$, plates were

washed, and rabbit anti-goat IgG conjugated to horseradish peroxidase was added to each well and incubated for an additional hour at $37^{\circ} \mathrm{C}$. After washing, horseradish peroxidase that remained in each well was quantitated as the absorption at $405 \mathrm{~nm}$ (ordinate) of the reaction product of $o$-phenylenediamine. In all studies, reaction product resulting from a parallel incubation with nonimmune serum was subtracted from that obtained with anti-OABP. 
Table I. Content of OABP in Tissue

Homogenates as Determined by ELISA*

\begin{tabular}{ll}
\hline Tissue & OABP (\% Total protein) \\
\hline Brain & 0.19 \\
Heart & 0.90 \\
Lung & 0.20 \\
Stomach & 0.49 \\
Duodenum & 0.24 \\
Jejunum & 0.35 \\
Ileum & 0.32 \\
Large intestine & 0.56 \\
Spleen & 0.23 \\
Kidney & 0.51 \\
Skeletal muscle & 0.48 \\
Liver & 0.18 \\
\hline
\end{tabular}

* Anti-OABP (0.36 ml of a 1:800 dilution) was absorbed overnight at $4^{\circ} \mathrm{C}$ with 4-15 $\mu \mathrm{g}$ of organ homogenate prepared in protease inhibitors $(400 \mathrm{U} / \mathrm{ml}$ aprotinin, $5 \mathrm{mM}$ EDTA, and $0.1 \mathrm{mM}$ phenylmethylsulfonyl fluoride). Absorbed antibody was used in an ELISA performed in microtiter plates coated with OABP $(1 \mu \mathrm{g} / \mathrm{ml})$. Results were compared with that obtained with antibody preabsorbed against known amounts of OABP as in Fig. 1.

or rat serum (Fig. 3), or when nonimmune serum was used. Similar results were obtained with the goat antibody.

Heart contained large amounts of immunoreactive OABP. To determine whether the heart protein possessed organic anion-binding activity, BSP-affinity chromatography of deoxycholate solubilized heart homogenate was performed. The eluted protein, subjected to SDS-PAGE followed by immunoblotting on nitrocellulose, migrated to the same position as did OABP in heart homogenate (Fig. 4).

To confirm the presence of OABP on the liver cell plasma membrane, we performed immunofluorescence studies on short-term cultured hepatocytes. As seen in Fig. 5, after antiOABP incubation, there was surface reactivity that was not seen after incubation with nonimmune serum or absorption of serum against liver or heart homogenates.

Subfractions of rat liver cell plasma membrane were examined to determine whether there was a domain specificity

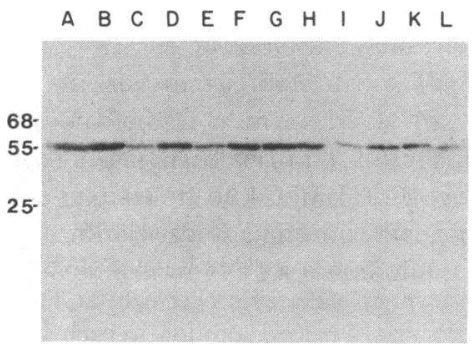

Figure 2. Radioautogram of immunoblot of rat organ homogenates with rabbit anti-rat OABP. Rat organ homogenates $(\approx \mathbf{4 0} \mathrm{ug})$ were subjected to $10 \%$ SDS-PAGE in $5 \% \beta$-mercaptoethanol. Proteins were transferred to nitrocellulose paper which was soaked for $1 \mathrm{~h}$ in rabbit anti-rat $\mathrm{OABP}$ (1:100 dilution). After washing, the nitrocellulose was incubated with $10^{6} \mathrm{cpm}$ of ${ }^{125} \mathrm{I}$-protein A, washed, and exposed to Kodak XAR-5 Xray film (Eastman Kodak Co.) for $4 \mathrm{~h}$ at $-70^{\circ} \mathrm{C}$. A parallel experiment using nonimmune rabbit serum revealed no reactivity. The organs studied are in lanes as follows: $(A)$ brain; $(B)$ heart; $(C)$ lung; $(D)$ stomach; $(E)$ duodenum; $(F)$ jejunum; $(G)$ ileum; $(H)$ colon; $(I)$ spleen; $(J)$ kidney; $(K)$ skeletal muscle; and $(L)$ liver. Migration of molecular weight standards (e.g., $68=68,000$ ) is indicated at the left.

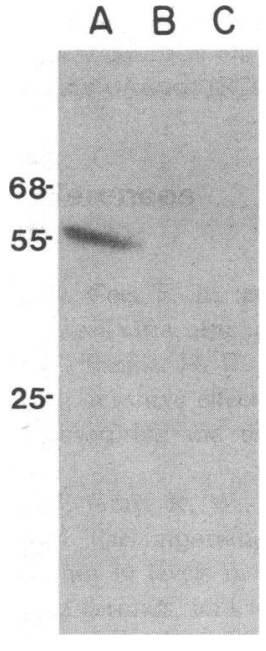

Figure 3. Radioautogram of Immunoblot of rat liver, plasma, and red cells with rabbit anti-rat OABP. Experimental details were as in Fig. 2. Liver homogenate is in lane $A$; plasma and red cells are in $B$ and $C$, respectively. Migration of molecular weight standards (e.g., $68=68,000)$ is indicated at the left.

in the distribution of OABP. There was no detectable OABP in the canalicular fraction by ELISA assay and Western blot, despite a 120-fold enrichment in $5^{\prime}$ nucleotidase activity over homogenate levels. OABP in the sinusoidal fraction, previously shown to be enriched in insulin and glucagon receptors (7, 17), was enriched 13.5-fold as compared with homogenate by ELISA. Western blot analysis revealed a single 55,000-mol wt band in this fraction. After high speed centrifugation of liver homogenate and high salt wash of the pellet, $>85 \%$ of starting OABP remained membrane bound.

\section{Discussion}

Although organic anions such as bilirubin and BSP circulate bound to albumin, they are rapidly and efficiently removed from the circulation by hepatocytes $(3,5)$. These compounds are extracted from albumin $(3,4,18,19)$ and enter the hepatocyte by a process having carrier-mediated kinetics (5, 6). The nature of this putative carrier is not known. Previous investigators suggested that hepatocyte cytosolic OABPs, of

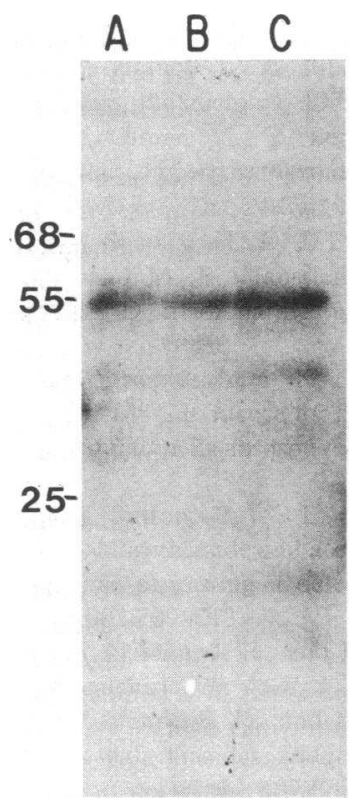

Figure 4. Radioautogram of immunoblot of OABP, rat heart homogenate, and BSP-sepharose purified heart protein with goat anti-rat OABP. OABP $(\approx 1 \mu \mathrm{g})$ (lane $A)$, heart homogenate $(\approx 40 \mu \mathrm{g})(B)$, and BSPsepharose purified heart protein $(\approx 1$ $\mu \mathrm{g})(C)$ were subjected to $10 \%$ SDSPAGE in 5\% $\beta$-mercaptoethanol. Proteins were transferred to nitrocellulose paper that was soaked for $1 \mathrm{~h}$ in goat anti-rat OABP (1:100 dilution). After washing, the nitrocellulose was incubated in $10^{6} \mathrm{cpm}$ of ${ }^{125}$ I-rabbit antigoat IgG. The sheet was washed and exposed to Kodak XAR-5 X-ray film (Eastman Kodak Co.) for $12 \mathrm{~h}$ at $-70^{\circ} \mathrm{C}$. A parallel experiment using nonimmune goat serum revealed no reactivity. Migration of molecular weight standards (e.g., $68=68,000$ ) is indicated at the left. 

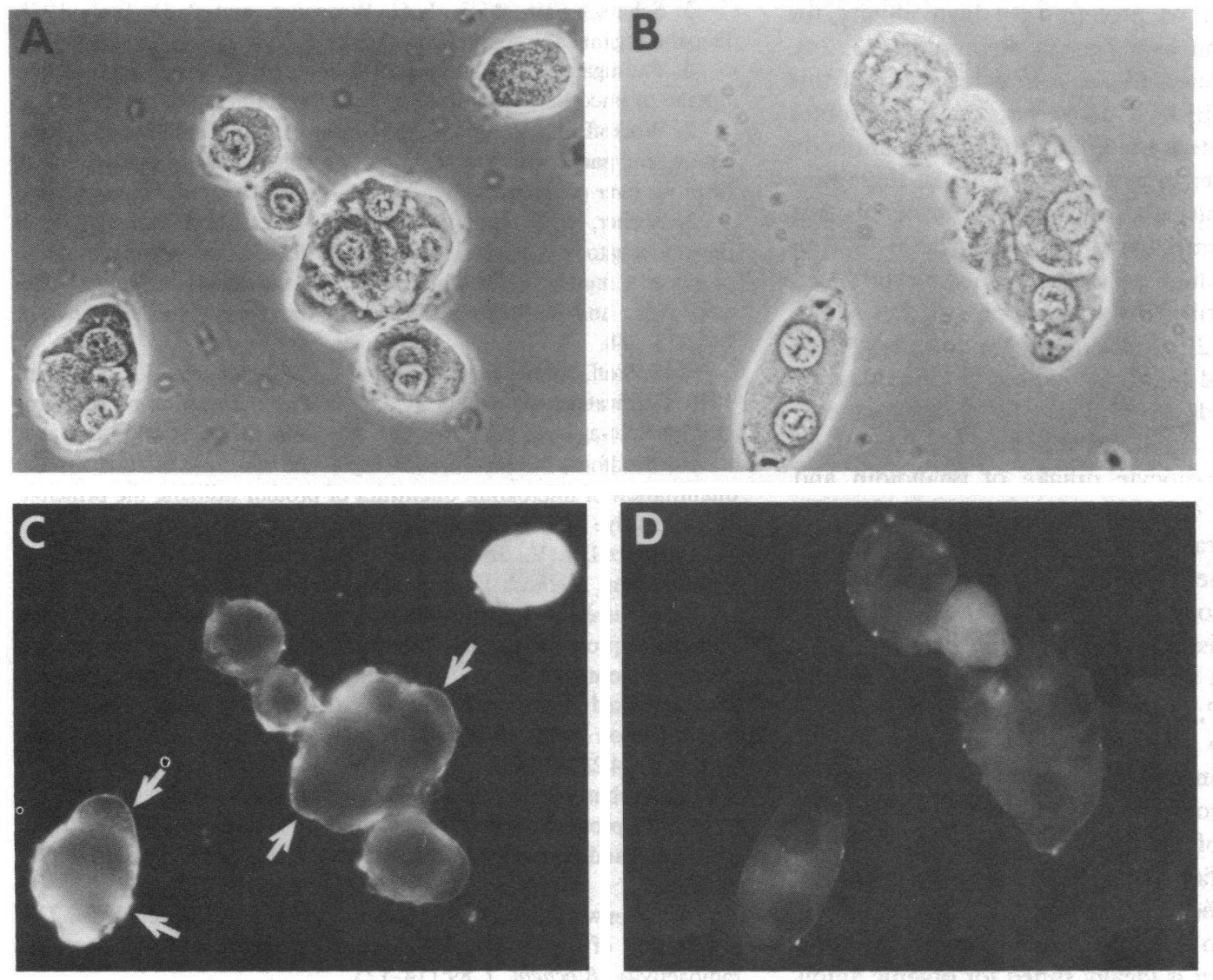

Figure 5. Immunofluorescence of goat anti-rat OABP in short term cultured hepatocytes. Rat hepatocytes were isolated after collagenase perfusion and cultured on collagen-coated coverslips for $24 \mathrm{~h}$. After a 2-min fixation in acetone at $-70^{\circ} \mathrm{C}$, coverslips were incubated with goat anti-rat OABP (A-phase micrograph, $\mathrm{C}$-fluorescence micrograph)

which ligandin is the most abundant, mediated uptake of organic anions (20). However, that influx of organic anions results from interaction with the cell surface was suggested from studies performed in isolated perfused rat liver in which altered ligandin concentration had no influence on influx of bilirubin (19). Ligandin content correlated inversely with efflux of bilirubin that had entered cells. Thus, ligandin influences only net uptake (the difference of influx and efflux) of bilirubin by reducing efflux of ligand from the cell.

To account for the rapid influx of organic anions into hepatocytes, an OABP on the liver cell plasma membrane was postulated (7). Photoaffinity activation of BSP in the presence of a sinusoidal liver plasma membrane fraction revealed specific binding to a 55,000 -mol wt protein (7). This OABP was purified from deoxycholate solubilized membrane by BSPSepharose affinity chromatography $(7,9)$. Using specific antisera to OABP, we have now studied its tissue distribution.

The ELISA used in these studies takes advantage of the fact that OABP adsorbs readily onto plastic. Its advantage over a radioimmunoassay is that OABP loses antigenicity even with mild radioiodination procedures. Quantitation of OABP in tissues was performed after absorption of antisera against tissue homogenates that contained protease inhibitors. Loss of antibody activity could be due to factors other than interaction with antigen, such as retained protease activity or nonspecific absorption of antibody to membrane. For this reason, immu- or nonimmune goat serum (B-phase, D-fluorescence), followed by rhodamine conjugated rabbit anti-goat IgG. As indicated by the arrows in $C$, surface reactivity is seen in cells incubated with antiOABP but not with nonimmune serum.

noblotting was used to confirm the presence of OABP in all tissues that were investigated by ELISA.

These studies indicate that OABP is present in significant amounts in all tissues examined except for blood. Although OABP has not as yet been isolated from each of these tissues and characterized, OABP in heart retains the ability to bind organic anions, and was purified by affinity chromatography on BSP-sepharose. In liver, the protein is membrane bound, and remains so after extraction with $0.9 \mathrm{M} \mathrm{NaCl}$, which suggests that OABP is an integral membrane protein. OABP does not have a ubiquitous subcellular distribution within the hepatocyte. Preparation of subfractions of liver cell plasma membrane reveal that OABP is present in the sinusoidal and absent from the canalicular membranes. The immunofluorescence studies performed in short-term cultured hepatocytes suggest that OABP is associated with the surface of these cells and does not have a significant intracellular distribution, although this technique may not be sensitive enough to reveal small amounts of OABP in intracellular locations.

Several other groups have identified liver cell surface binding proteins for organic anions. Lunazzi and colleagues (21) have purified a protein from an acetone powder of rat liver. This protein, which has been named bilitranslocase, is comprised of 37,000- and 35,500-mol wt subunits (21), and has been reported as mediating BSP transport into liposomes in which it has been incorporated (22). Berk et al. reported 
isolation of a 55,000-mol wt protein with high affinity for bilirubin and BSP from rat liver plasma membrane $(23,24)$. Preliminary studies (25) revealed weak cross-reactivity of this protein and OABP on ELISA. However, on immunoblot analysis, there was no reactivity of OABP to the Berk antibody (unpublished data). Further comparative studies of these proteins will be necessary to elucidate structural and immunological similarities. Liver cell membrane proteins of $54,000 \mathrm{~mol} \mathrm{wt}$ that bind bile acids with high affinity and mediate bile acid transport have been described by von Dippe and Levy (2628) and by Ziegler et al. (29). Although it has been suggested that the organic anion and bile acid binding proteins may be related $(-29)$, there is no direct evidence for this hypothesis. Recent observations have indicated that the $54,000-\mathrm{mol}$ wt protein also mediates hepatocyte uptake of phalloidin and antaminide but not BSP $(30,31)$. Also suggesting that the 54,000 -mol wt bile acid transport protein differs from OABP is the finding that it is absent from small intestine, as defined by photoaffinity methodology (32). The immunological distribution of this protein in tissues is not as yet available.

Although these studies were not designed to elucidate the possible function of OABP, the widespread distribution of this protein raises doubt as to whether it plays a unique role in hepatic organic anion transport. Failure of other organs to transport organic anions could be due to internal rather than cell surface localization of OABP; recent light microscopic immunocytochemical studies have revealed that this is not the case (33). However, specificity of the liver for organic anion transport may be due to factors in addition to requisite transport proteins. The liver is ideally suited for organic anion removal. Many of these compounds are avidly bound to albumin in the circulation, and only in the liver do sinusoidal fenestrations permit protein-bound ligand to interact directly with the plasma membrane $(19,34,35)$. Thus, even if other organs have an identical transport system for organic anions, the liver may extract them preferentially. In liver dysfunction, other organs, such as kidney, may take up these molecules. Definition of the function of OABP requires additional investigation. The presence of OABP in short-term cultured hepatocytes suggests that this may be an ideal system in which to conduct such studies.

\section{Acknowledgments}

These studies were supported by National Institutes of Health grants AM-23026, AM-17702, AM-32419, and AM-32972.

\section{References}

1. Gray, R. D., and S. S. Stroupe. 1978. Kinetics and mechanisms of bilirubin binding to human serum albumin. J. Biol. Chem. 253: 4370-4377.

2. Baker, K. J., and S. E. Bradley. 1966. Binding of sulfobromophthalein sodium by plasma albumin. Its role in hepatic sulfobromophthalein extraction. J. Clin. Invest. 45:281-287.

3. Stollman, Y. R., U. Gartner, L. Theilmann, N. Ohmi, and A. W. Wolkoff. 1983. Hepatic bilirubin uptake in the isolated perfused rat liver is not facilitated by albumin binding. J. Clin. Invest. 72:718723.

4. Theilmann, L., Y. R. Stollman, I. M. Arias, and A. W. Wolkoff. 1984. Does Z-Protein have a role in transport of bilirubin and bromosulfophthalein by isolated perfused rat liver? Hepatology. 4:923926.
5. Scharschmidt, B. F., J. G. Waggoner, and P. D. Berk. 1975. Hepatic organic anion uptake in the rat. J. Clin. Invest. 56:1280-1292.

6. Paumgartner, G., and J. Reichen. 1976. Kinetics of hepatic uptake of unconjugated bilirubin. Clin. Sci. Mol. Med. 51:169-176.

7. Wolkoff, A. W., and C. T. Chung. 1980. Identification, purification, and partial characterization of an organic anion binding protein from rat liver cell plasma membrane. J. Clin. Invest. 65:1152-1161.

8. Wisher, M. H., and W. H. Evans. 1975. Functional polarity of the rat hepatocyte plasma membrane. Isolation and characterization of plasma membrane subfractions from the blood-sinusoidal, bilecanalicular and contiguous surfaces of the hepatocyte. Biochem. J. 146:375-388.

9. Wolkoff, A. W., M. M. Bhargava, C. Chung, and Z. Gatmaitan. 1979. Purification of ligandin by affinity chromatography on sulfobromophthalein-agarose gel. Proc. Soc. Exp. Biol. Med. 160:150-153.

10. Bradford, M. M. 1976. A rapid and sensitive method for the quantitation of microgram quantities of protein utilizing the principle of protein-dye binding. Anal. Biochem. 72:248-254.

11. Maizel, J. V., Jr. 1971. Polyacrylamide gel electrophoresis of viral proteins. Methods Virol. 5:179-246.

12. O'Farrell, P. H. 1975. High resolution two-dimensional electrophoresis of proteins. J. Biol. Chem. 250:4007-4021.

13. Notermans, S., A. M. Hagenaars, and S. Kozaki. 1982. The enzyme-linked immunosorbent assay (ELISA) for the detection and determination of Clostridium botulinum toxins A, B, and E. Methods. Enzymol. 84:223-238.

14. Towbin, H., T. Staehelin, and J. Gordon. 1979. Electrophoretic transfer of proteins from polyacrylamide gels to nitrocellulose sheets: procedure and some applications. Proc. Natl. Acad. Sci. USA. 76: 4350-4354.

15. Greenwood, F. C., W. M. Hunter, and J. S. Glover. 1963. The preparation of ${ }^{131} \mathrm{I}$-labelled human growth hormone of high specific radioactivity. Biochem. J. 89:114-123.

16. Wolkoff, A. W., R. D. Klausner, G. Ashwell, and J. Harford. 1984. Intracellular segregation of asialoglycoproteins and their receptor: a prelysosomal event subsequent to dissociation of the ligand-receptor complex. J. Cell Biol. 98:375-381.

17. Evans, W. H., J. J. M. Bergeron, and I. I. Geschwind. 1973. Distribution of insulin receptor sites among liver plasma membrane subfractions. FEBS (Fed. Eur. Biochem. Soc.) Lett. 34:259-262.

18. Goresky, C. A. 1965. The hepatic uptake and excretion of sulfobromophthalein and bilirubin. Can. Med. Assoc. J. 92:851-857.

19. Wolkoff, A. W., C. A. Goresky, J. Sellin, Z. Gatmaitan, and I. M. Arias. 1979. The role of ligandin in the transfer of bilirubin from plasma into the liver. Am. J. Physiol. 236:E638-E648.

20. Fleischner, G., J. Robbins, and I. M. Arias. 1972. Immunological studies of Y Protein. A major cytoplasmic organic anion-binding protein in rat liver. J. Clin. Invest. 51:677-684.

21. Lunazzi, G., C. Tiribelli, B. Gazzin, and G. Sottocasa. 1982. Further studies on bilitranslocase, a plasma membrane protein involved in hepatic organic anion uptake. Biochem. Biophys. Acta. 685:117122.

22. Sottocasa, G. L., G. Baldini, G. Sandri, G. Lunazzi, and C. Tiribelli. 1982. Reconstitution in vitro of sulfobromophthalein transport by bilitranslocase. Biochim. Biophys. Acta. 685:123-128.

23. Reichen, J., and P. D. Berk. 1979. Isolation of an organic anion-binding protein from rat liver plasma membrane fractions by affinity chromatography. Biochem. Biophys. Res. Commun. 91:484489.

24. Stremmel, W., M. A. Gerber, V. Glezerov, S. N. Thung, S. Kochwa, and P. D. Berk. 1983. Physiochemical and immunohistological studies of a sulfobromophthalein and bilirubin-binding protein from rat liver plasma membrane. J. Clin. Invest. 71:1796-1805.

25. Wolkoff, A. W., A. Sosiak, J. Van Renswoude, and R. J. Stockert. 1983. Immunological localization of an organic anion binding protein (OABP) isolated from rat liver cell plasma membrane. Hepatology. 3:875. (Abstr.)

26. von Dippe, P., and D. Levy. 1983. Characterization of the bile 
acid transport system in normal and transformed hepatocytes. J. Biol. Chem. 258:8896-8901.

27. Levy, D., and P. von Dippe. 1982. Reconstitution of the bile acid transport system derived from hepatocyte sinusoidal membranes. Hepatology. 3:839. (Abstr.)

28. Levy, D., M. Ananthanarayanan, and P. von Dippe. 1984. Immunological characterization of the hepatocyte bile acid transport system. Hepatology. 4:1032. (Abstr.)

29. Ziegler, K., M. Frimmer, and H. Fasold. 1984. Further characterization of membrane proteins involved in the transport of organic anions in hepatocytes. Comparison of two different affinity labels: 4,4'diisothiocyano-1,2-diphenylethane-2,2'-disulfonic acid and brominated taurodehydrocholic acid. Biochim. Biophys. Acta. 769:117-129.

30. Petzinger, E., C. Joppen, and M. Frimmer. 1983. Common properties of hepatocellular uptake of cholate, iodipamide, and antamanide, as distinct from the uptake of bromosulfophthalein. NaunynSchmiedbergs Arch. Pharmakol. 322:174-179.
31. Weiland, T., M. Nassal, W. Kramer, G. Fricker, U. Bickel, and G. Kurz. 1984. Identity of membrane transport systems for bile salts, phalloidin, and antamanide by photoaffinity labeling. Proc. Natl. Acad. Sci. USA. 81:5232-5236.

32. Kramer, W., G. Burchhardt, F. A. Wilson, and G. Kurz. 1983. Bile salt-binding polypeptides in brush-border membrane vesicles from rat small intestine revealed by photoaffinity labeling. J. Biol. Chem. 258:3623-3627.

33. Inagaki, T., P. M. Novikoff, A. B., Novikoff, R. J. Stockert, and A. W. Wolkoff. 1985. Immunocytochemical localization of OABP and HBP in kidney, heart, and GI tract. Gastroenterology. 88:1666. (Abstr.)

34. Goresky, C. A. 1963. A linear method for determining liver sinusoidal and extravascular volumes. Am. J. Physiol. 204:626-640.

35. Wisse, E., and D. L. Knook. 1979. The investigation of sinusoidal cells: a new approach to the study of liver function. Prog. Liver Dis. 6:153-171. 